TRANSFORMATIKA, Vol.16, No.2, Januari 2019, pp. 144 - 152

ISSN: 1693-3656,

journals.usm.ac.id/index.php/transformatika

page 144

\title{
PENERAPAN EKSTRAKSI PENGETAHUAN DALAM PEMBAYARAN PERKULIAHAN MENGGUNAKAN SOFT SYSTEM METHODOLOGY (STUDI KASUS: PERGURUAN TINGGI X)
}

\author{
${ }^{1}$ Munifah, ${ }^{2}$ Ade Iriani, ${ }^{3}$ Sri Yulianto Joko Prasetyo \\ ${ }^{1}$ Program Studi Sistem Informasi Universitas Kristen Satya Wacana \\ Salatiga, Indonesia, e-mail: khaffah@yahoo.com \\ 2 Program Studi Sistem Informasi Universitas Kristen Satya Wacana \\ Salatiga, Indonesia, e-mail: adeiriani@gmail.com \\ ${ }^{3}$ Program Studi Sistem Informasi Universitas Kristen Satya Wacana \\ Salatiga, Indonesia, e-mail: sri.yulianto@staff.uksw.edu
}

\section{ARTICLE INFO}

Article history:

Received 17 Desember 2018

Received in revised form 17 Desember 2018

Accepted 25 Desember 2018

Available online 31 Januari 2019

\begin{abstract}
Education is the most important part of the national development process, besides that education is also an economic determinant of a country. As an educational institution, Higher Education is obliged to provide the best education for students studying at the College, and vice versa students who obtain knowledge at Higher Education are required to pay for college. Tuition fees are fees that must be paid by students. The attitude of delaying the payment of tuition made by students towards universities that provides academic services clearly presents several disadvantages.

The incident gave rise to various requests from the management of Higher Education regarding the importance of handling compensation and imposition of sanctions to provide a deterrent effect to students. The problem that arises is how to extract knowledge on student tuition payments $\mathrm{X}$ College. the purpose is to make modeling in the process of knowledge extraction on the payment of lectures with Soft System methodology. After examining the terms of payment for lectures and fines in College $\mathrm{X}$, the results of this study are modeling knowledge extraction in lecture payments
\end{abstract}

Keywords: soft system methodology, knowledge extraction, lecture payment

\section{Pendahuluan}

Pendidikan merupakan bagian terpenting dari proses pembangunan nasional, selain itu pendidikan juga merupakan penentu ekonomi dari suatu Negara. Perguruan Tinggi merupakan lembaga ekonomi yang didirikan atau diselenggarakan oleh masyarakat. Makin banyaknya perguruan tinggi yang ada menyebabkan persaingan dalam merebut pangsa pasar semakin ketat. Hal ini karena perguruan tinggi sebagai suatu institusi yang bergerak dibidang jasa harus dapat memberikan pelayanan jasa dibidang 
pendidikan yang berkualitas dan harus selalu memenuhi kebutuhan dan keinginan para pengguna jasa, salah satunya adalah mahasiswa. Pelayaan akademik dalam perguruan tinggi meliputi berbagai bentuk pelayanan salah satunya dalam hal pembayaran perkuliahan.

Pembayaran SPP adalah salah satu contoh kegiatan ekonomi dan bisnis setiap individu mahasiswa. SPP merupakan biaya yang wajib dibayar oleh para mahasiswa secara rutin untuk bisa mengikuti perkuliahan atau bagi yang terlambat membayar SPP ini akan di kenakan denda atau akan discoursing tidak dapat mengikuti kuliah selama belum membayar SPP. Mahasiswa pada kasus ini menduduki posisi yang rendah dan dalam satu kondisi tertentu diharuskan mengambil pilihan yang tidak populer. Kasus yang sering terjadi para mahasiswa di Perguruan Tinggi $\mathrm{X}$ terlambat membayar karena lalai, nakal (menunda-nunda pembayaran), ekonomi rendah.

Banyaknya tuntutan mendesak pihak Perguruan Tinggi supaya menghapuskan denda bagi mahasiswa yang terlambat membayar iuran perkuliahan banyak kita jumpai akhir-akhir ini, karena dianggap menambah beban mahasiswa yang ekonominya rendah juga penggunaan dana yang terkumpul dari hasil denda tersebut ditengarai tidak transparan dan akuntabel.

Sikap keterlambatan dalam membayar iuran perkuliahan yang dilakukan oleh mahasiwa terhadap pihak Perguruan Tinggi X yang memberikan pelayanan akademik jelas menghadirkan beberapa kerugian. Kejadian ini memunculkan berbagai permintaan dari pengelola Perguruan Tinggi akan pentingnya penanganan ganti rugi dan pengenaan sanksi, ganti rugi atas biaya yang dikeluarkan kepada mahasiswa yang lalai, yang belum mampu membayar dan nakal (menunda-nunda pembayaran). Pengenaan denda pada iuran perkuliahan mahasiswa untuk memberikan efek jera kepada mahasiswa.

Soft System Methodology (SSM) dipilih sebagai pendekatan untuk memecahkan masalah yang dihadapi mahasiswa dan Perguruan Tinggi X. Sehingga tidak menghambat proses pembayaran perkuliahan terhadap mahasiswa. Maani dan Cavana membagi pendekatan dalam berpikir serbasistem menjadi dua, yaitu hard systems dan soft system [1]. hard system digunakan untuk menganalisis masalah yang sudah terstuktur dengan jelas, sedangkan soft system digunakan ntuk menganalisis masalah yang tidak terstuktur dengan jelas dan belum terdefinisi dengan baik. Soft system methodhology (SSM) merupakan metodologi sebagai pembaharuan dari hard system methodhology (HSM) yang pola pikirnya adalah membatasi jumlah variabel seminimum mungkin sehingga dapat menyederhanakan masalah dan memudahkan perumusan formulasi solusi [2].

Berdasarkan latar belakang diatas maka dapat dirumuskan permasalahan sebagai berikut: bagaimana penerapan ekstraksi pengetahuan dalam pembayaran perkuliahan menggunakan soft system methodology.

\section{Metode Penelitian}

Methodologi dalam ekstraksi pengetahuan ini menggunakan SSM (Soft System Methodology) dengan beberapa langkah ditambahkan pada studi kasus. Berikut ini akan dijelaskan dalam kerangka pemecahan masalah pada gambar 1 dibawah ini. 


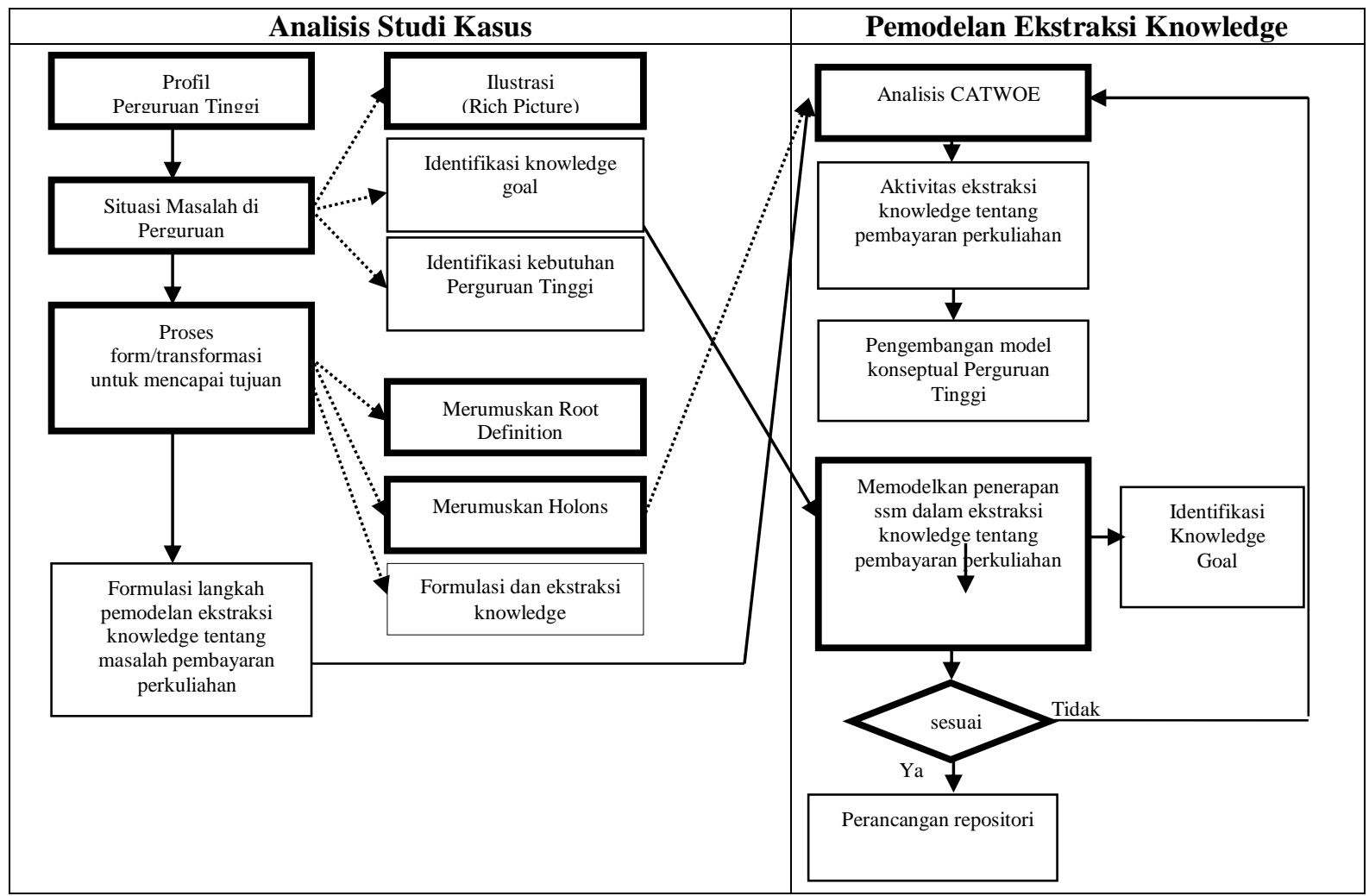

Gambar 1. Kerangka Pemecahan Masalah

Dalam pemecahan masalah terbagi menjadi dua kategori yaitu proses analisis studi kasus dan pemodelan ekstraksi knowledge tentang pembayaran perkuliahan yang akan menjadi model terakhir dari penelitian ini.

Proses analisis studi kasus yaitu:

1. Profil Perguruan Tinggi

Langkah pertama yaitu melakukan wawancara kepada para staff administrasi, sehingga diperoleh tugas dari masing-masing staff, tujuan Perguruan Tinggi dan proses pembayaran perkuliahan dan melakukan observasi langsung di tempat penelitian.

2. Situasi Masalah di Perguruan Tinggi

Mengidentifikasi atau mengungkapkan secara singkat tentang situasi yang ada di dalam perguruan tinggi kedalam Rich Picture, mengidentifikasi knowledge goal dan kebutuhan perguruan tinggi.

3. Proses transformasi untuk mencapai tujuan

Menjelaskan proses transformasi, merumuskan holon dipetakan dalam elemen CATWOE, merumuskan RD dan formulasi ekstraksi pengetahuan.

4. Formulasi langkah pemodelan ekstraksi pengetahuan tentang masalah pembayaran perkuliahan.

5. Analisis CATWOE

Analisis CATWOE untuk tiap holon yang dirumuskan

6. Aktivitas ekstraksi pengetahuan

Melakukan ekstraksi pengetahuan dari proses pembayaran perkuliahan

7. Pengembangan model konseptual Perguruan Tinggi

Membuat model konseptual sesuai dengan kebutuhan perguruan tinggi

8. Memodelkan penerapan ssm dalam ekstraksi knowledge tentang pembayaran perkuliahan

Membuat pemodelan yang menerapkan SSM dalam ekstraksi pengetahuan

9. Perancangan repository

Merancang repository yang diperoleh dari proses penerapan SSM

Penelitian ini menggunakan metode yang disebut SSM untuk mengekstrak pengetahuan dalam pembayaran perkuliahan di perguruan tinggi x. SSM terdiri dari tujuh langkah. Langkah-langkah dan implementasi metode ditunjukkan pada Gambar 2. 


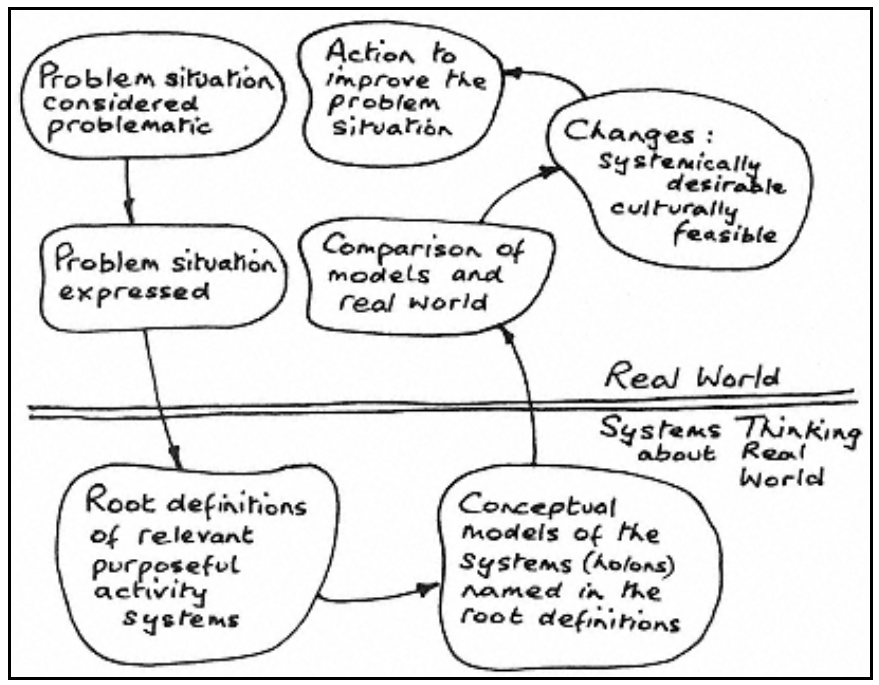

Gambar 2. Kerangka Kerja SSM

Penjelasan Gambar 2 sebagai berikut:

1) Problem Situation

Pada langkah pertama ini, dibuat dengan identifikasi dan deskripsi singkat tentang situasi atau masalah yang terjadi di perguruan tinggi. Untuk mengetahui masalah dengan melakukan wawancara dan observasi.

2) Problem Situation Expressed

Langkah kedua, mengumpulkan data dan informasi. Data dan informasi dikumpulkan dengan wawancara dan observasi kemudian dibentuk menjadi Rich Picture.

3) Root Definition

Langkah ketiga membuat Root Definition (RD), menjelaskan proses transformasi. Merumuskan $\mathrm{RD}$, merumuskan holon yang dipetakan dalam CATWOE untuk menyelesaikan masalah.

4) Conceptual Modeling

Langkah keempat adalah membuat model konseptual ekstraksi pengetahuan.

5) Comparison of Models and Real World

Langkah kelima melakukan perbandingan antara sketsa situasi riil dengan model yang dibuat.

6) Change

Langkah keenam hasil dari langkah sebelumnya dibahas bersama dengan pihak yang berkepentingan. Melakukan perubahan atau penyesuaian, jika ada perbedaan maka dilakukan penyesuaian-penyesuaian hingga model konseptual sudah sesuai dengan situasi riil.

7) Action to Improve the Problem Situation

Langkah terakhir melakukan rekomendasi-rekomendasi perbaikan terhadap prosedur yang lama 


\section{Hasil dan Pembahasan}

Berdasarkan tujuh tahap SSM, berikut adalah penjelasan hasil dan pembahasan yang diperoleh dari masing-masing tahapan yang diteliti:

\subsection{Identifikasi Masalah}

Berdasarkan uraian diatas beberapa masalah dalam pembayaran perkuliahan yang diperoleh dari penelitian ini adalah masih banyaknya mahasiswa yang terlambat membayar iuran kuliah seperti uang SPP, uang semesteran dan uang gedung. Walaupun sudah diberi sanksi bagi mahasiswa yang terlambat membayar. Keterlambatan tersebut dikarenakan beberapa hal antara lain: lalai, menundanunda pembayaran, ekonomi rendah.

\subsection{Mengungkapkan Masalah kedalam Rich Picture}

Proses pengungkapan situasi pembayaran perkuliahan Perguruan Tinggi dalam bentuk rich picture. Rich picture dapat dilihat pada gambar 3 .

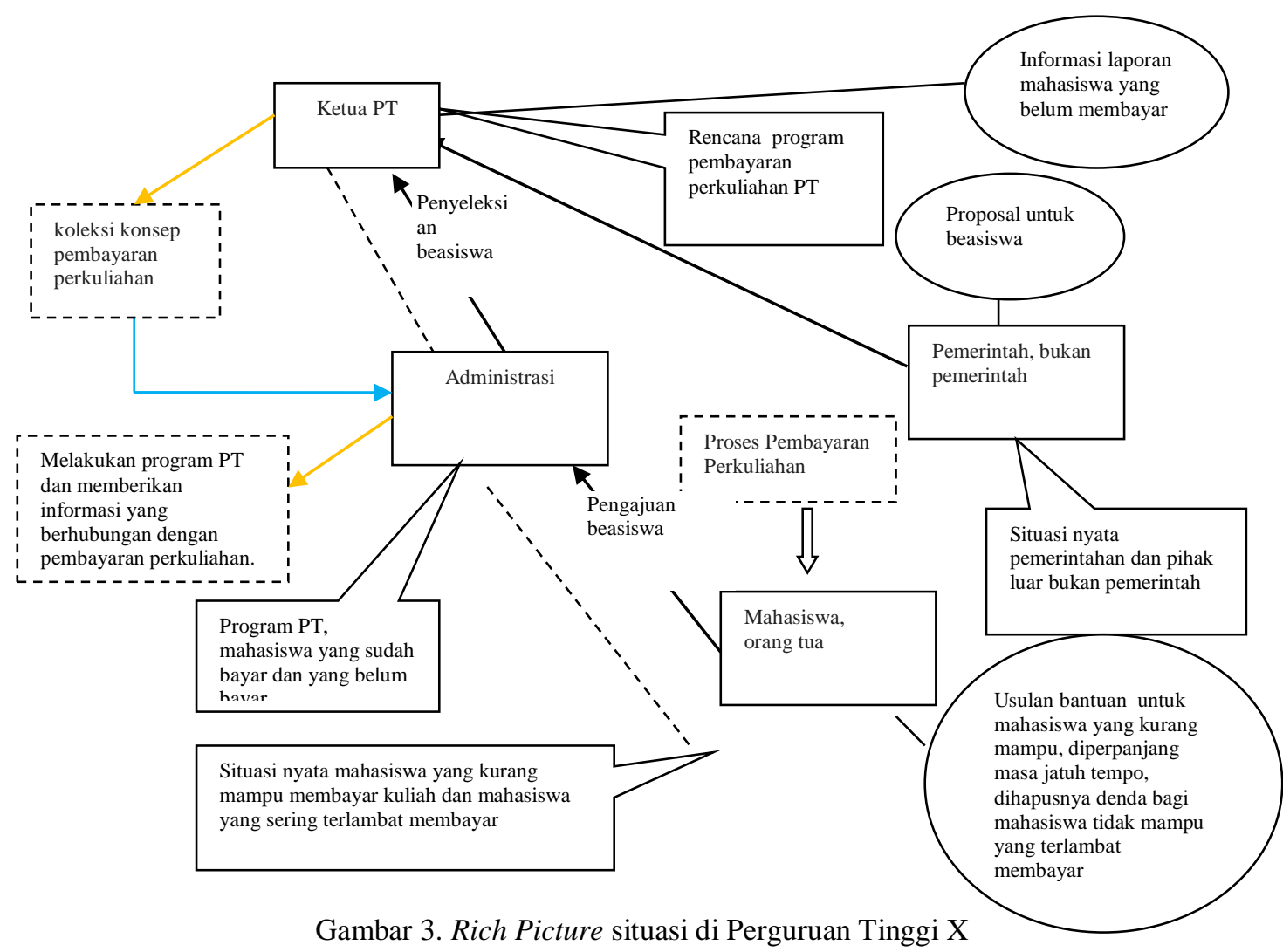

Pada gambar rich picture diatas dijelaskan situasi di Perguruan Tinggi, tentang aktor yang terlibat dalam kegiatan pembayaran perkuliahan. Para aktor berasal dari dalam Perguruan Tinggi, seperti ketua Perguruan Tinggi dan Administrasi. Sedangkan aktor yang berasal dari luar Perguruan Tinggi yaitu mahasiswa, orang tua, pemerintah dan non pemerintah. Rich picture memberikan pemetaan tentang keterkaitan pelaku-pelaku dalam pembayaran perkulihan, apa yang diketahui pelaku dan keadaan yang menggambarkan kebutuhan setiap pelaku yang belum terpenuhi. Jika masalah keterlambatan pembayaran perkuliahan tidak ditangani maka akan menghambat kegiatan operasional perguruan tinggi, jika tidak ditangani berlarut-larut akan merugikan perguruan tinggi.

\subsection{Root Definition}

Untuk Merumuskan Root Definition dan holon dipetakan dalam analisis CATWOE untuk menyelesaikan masalah sebagai berikut:

Tabel 1. Analisis CATWOE

\begin{tabular}{|l|l|l|}
\hline C & Customer & Ketua PT, Mahasiswa, Orang tua mahasiswa \\
\hline A & Actor & Administrasi, Perguruan Tinggi, Pihak Luar PT \\
\hline T & Transformation & Untuk mewujudkan proses pembayaran perkuliahan yang tertib yang \\
\hline
\end{tabular}




\begin{tabular}{|l|l|l|}
\hline & & $\begin{array}{l}\text { mendapat dukungan penuh dari perguruan tinggi x dan untuk } \\
\text { melibatkan peran aktif orang tua mahasiswa dalam memantau anaknya } \\
\text { serta peran aktif administrasi berbagi pengetahuan serta pengalaman } \\
\text { yang dimiliki }\end{array}$ \\
\hline $\mathrm{W}$ & $\begin{array}{l}\text { Weltanschuung } \\
\text { (World view) }\end{array}$ & $\begin{array}{l}\text { Semua pihak yang berkepentingan bertanggungjawab untuk } \\
\text { mewujudkan proses pembayaran perkuliahan yang tertib }\end{array}$ \\
\hline $\mathrm{O}$ & Owner & Ketua PT, Administrasi \\
\hline $\mathrm{E}$ & $\begin{array}{l}\text { Environmental } \\
\text { Constraints }\end{array}$ & $\begin{array}{l}\text { - Perlunya informasi bagi mahasiswa yang belum membayar } \\
- \text { Tidak pengaruhnya denda, karena masih banyak mahasiswa yang } \\
\text { terlambat membayar } \\
\text { - Perlunya tambahan beasiswa bagi mahasiswa yang tidak mampu }\end{array}$ \\
\hline
\end{tabular}

\subsection{Model Konseptual}

Dari sistem pembayaran perkuliahan yang dijabarkan, diperoleh beberapa unsur yang dapat membentuk model konseptual ekstraksi knowledge dibuat dalam gambar dibawah ini:

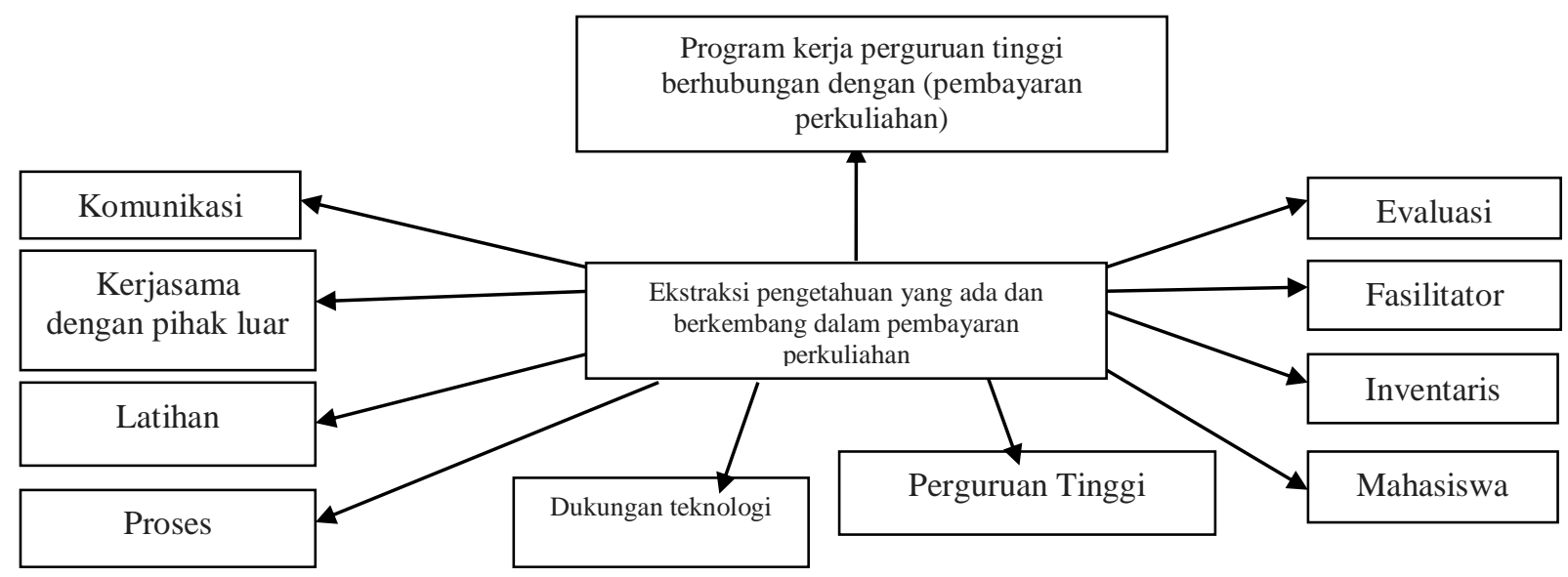

Gambar 4. Model Konseptual

Ekstraksi Pengetahuan Pembayaran Perkuliahan

Gambar 4 merupakan model konseptual yang dibangun berdasarkan rincian kegiatan pembayaran perkuliahan, kemudian membuat identifikasi root definition sebuah perspektif umum yang ingin dicapai. Untuk mencapai perspektif tersebut, dijabarkan faktor-faktor pendukung pencapaian perspektif. Dalam SSM, model konseptual biasanya menggambarkan faktor-faktor dalam bentuk kata kerja berupa hal-hal yang perlu dicapai untuk pencapaian Root Definition. Dalam penelitian ini model konseptual dibentuk dalam kata benda, karena setiap staff di Perguruan Tinggi dapat mengatur lebih dari satu faktor, masing-masing faktor dapat dikelola lebih dari satu staff ini bisa menghasilkan model konseptual yang sulit dipahami. Oleh karena itu model konseptual dibuat dalam bentuk kata benda dengan aktifitas yang berasal dari tahap deskripsi situasi pembayaran perkuliahan.

\subsection{Model Ekstraksi Pengetahuan Pembayaran Perkuliahan}

Sebagaimana telah dijelaskan pada bagian model konseptual yang menyebutkan bahwa ekstraksi pengetahuan yang ingin dicapai dalam pembayaran perkuliahan adalah root definition dari model konseptual, maka Gambar 5 akan menggambarkan konsep model ekstraksi pengetahuan yang dapat diterapkan di perguruan tinggi $\mathrm{x}$ untuk proses ekstraksi pengetahuan dalam pembayaran perkuliahan. 


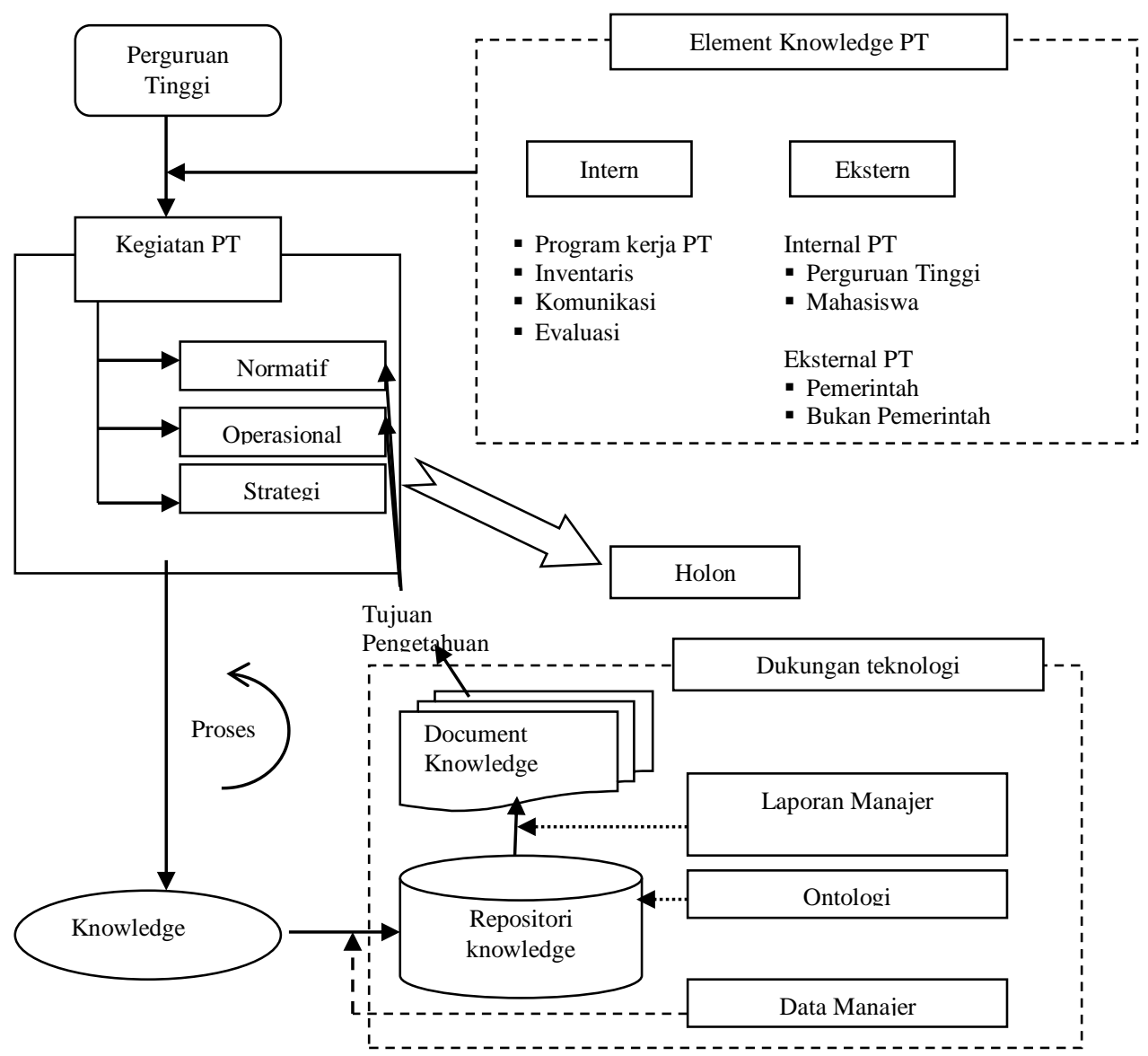

Gambar 5. Model Konseptual Penerapan SSM

Dalam Ekstraksi Pengetahuan Pembayaran Perkuliahan

Pada gambar 5 diatas menjelaskan bahwa ada unsur yang berkaitan dengan proses pembayaran kuliah dalam melakukan prosesnya. Elemen ini terlihat dalam kegiatan perkuliahan yang terbagi menjadi tiga tingkatan yaitu normatif, operasional dan strategi. Antara sumber pengetahuan dan hasil pengetahuan bisa dipasangkan. Tingkatan tersebut berdasarkan tujuan pengetahuan dalam penerapan KM didalam organisasi yang terdapat pada Knowledge Goals.

Kegiatan pembayaran perkuliahan menghasilkan perubahan yang diharapkan yang disebut dengan holon. Selain adanya holon, kegiatan pembayaran perkuliahan juga menghasilkan pengetahuan yang tidak terstruktur. Karena itu, dibutuhkan dukungan teknologi seperti data manajer dan laporan manajer sebagai alat yang membantu proses pencatatan pengetahuan ke dalam repository knowledge. Dalam repositori perlu dibuat ontologi sebagai suatu mekanisme yang dipilih untuk menstrukturkan data yang diperoleh.

Data manajer dan laporan manajer dibuat dalam bentuk software sesuai dengan pengetahuan yang berkembang. Model penerapan SSM dalam mengestrak pengetahuan tentang masalah pembayaran uang kuliah, data manajer dan laporan manajer merupakan sebuah fungsi dan dapat mengalami perubahan berupa perangkat input dan laporan yang dihasilkan sesuai dengan perkembangan pengetahuan yang ada.

Repositori pengetahuan penting untuk mendukung penyimpanan pengetahuan PT dalam bentuk terstruktur, sehingga ontologi digunakan dalam pengetahuan ini memiliki fungsi sebagai tata bahasa yang disediakan terkait dengan pengetahuan yang berkembang di sistem Pembayaran Perkuliahan. Sistem ini membutuhkan properti dalam repositori, sehingga properti bisa menyusun pengetahuan yang ada di PT. Dokumen pengetahuan sebagai hasil pengetahuan dapat memperkaya PT dan membantu PT untuk melakukan kegiatan. Dalam tujuan pengetahuan, sistem ini menetapkan pencapaian manajemen pengetahuan yang disusun dalam tiga macam tujuan yaitu normatif, operasional dan strategis. Dokumen pengetahuan dapat membantu kegiatan PT yang telah disesuaikan dengan konsep tujuan pengetahuan. 


\subsection{Perbandingan Antara Model dan Realita}

Tabel 2. Perbandingan Antara Model Konseptual dan Realita

\begin{tabular}{|c|c|c|}
\hline Aktivitas & Realita & Rekomendasi \\
\hline $\begin{array}{l}\text { Pelaksaan pembayaran } \\
\text { perkuliahan }\end{array}$ & $\begin{array}{l}\text { - Uang SPP yang dibayar } \\
\text { perbulan } \\
\text { - Uang semesteran yang } \\
\text { dibayar } 4 \text { bulan sekali atau } 6 \\
\text { bulan sekali } \\
\text { Kadang membuat mahasiswa lalai } \\
\text { dalam membayar perkuliahan. }\end{array}$ & 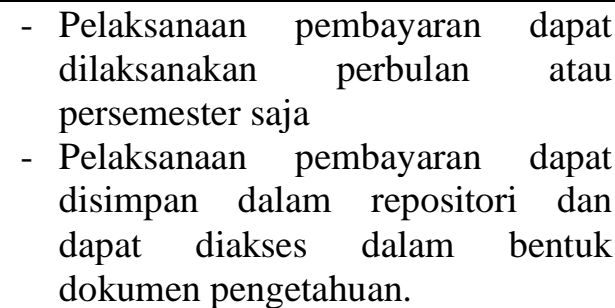 \\
\hline Pembayaran denda & 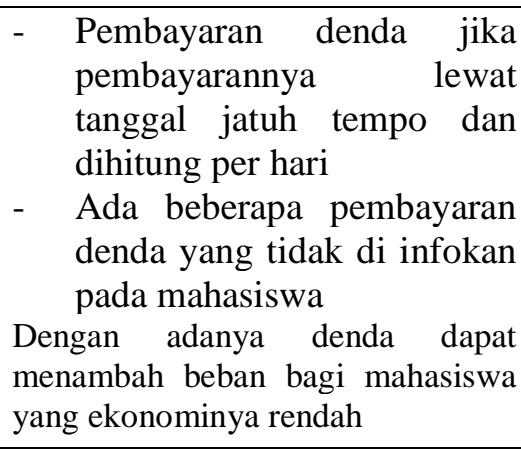 & $\begin{array}{l}\text { - Adanya suatu dispensasi } \\
\text { pembayaran denda bagi mahasiswa } \\
\text { tidak mampu } \\
\text { - Pihak administrasi menginfokan } \\
\text { semua biaya-biaya yang ditanggung } \\
\text { mahasiswa beserta nilai denda dan } \\
\text { tanggal jatuh temponya tanpa } \\
\text { terkecuali dalam repository yang } \\
\text { dapat diakses mahasiswa dan orang } \\
\text { tua mahasiswa }\end{array}$ \\
\hline $\begin{array}{l}\text { Beasiswa dari pihak PT } \\
\text { maupun pemerintah }\end{array}$ & $\begin{array}{l}\text { - } \begin{array}{l}\text { Selama ini beasiswa untuk } \\
\text { mahasiswa PT berasal dari } \\
\text { pemerintah } \\
\text { bidikmisi) }\end{array} \\
\end{array}$ & $\begin{array}{l}\text { - PT dapat memberikan beasiswa } \\
\text { kepada mahasiswa } \\
\text { - Adanya kerjasama antara PT } \\
\text { dengan pihak luar PT }\end{array}$ \\
\hline $\begin{array}{l}\text { Laporan pembayaran } \\
\text { perkuliahan }\end{array}$ & $\begin{array}{l}\text { - } \begin{array}{ll}\text { Pihak administrasi kurang } \\
\text { memberikan } & \text { informasi } \\
\text { mahasiswa yang terlambat } \\
\text { membayar }\end{array} \\
\end{array}$ & $\begin{array}{l}\text { - Setiap bulan pihak administrasi } \\
\text { sebaiknya menginformasikan } \\
\text { mahasiswa yang belum membayar } \\
\text { sehingga mahasiswa tidak dibebani } \\
\text { denda yang besar }\end{array}$ \\
\hline $\begin{array}{l}\text { Pantauan } \\
\text { mahasiswa }\end{array}$ & $\begin{array}{l}\text { - } \begin{array}{l}\text { Masih ada mahasiswa yang } \\
\text { menunda-nunda } \\
\text { pembayaran }\end{array} \\
\end{array}$ & $\begin{array}{l}\text { - Sebaiknya pihak administrasi dapat } \\
\text { menghubungi orang tua mahasiswa } \\
\text { yang sering terlambat membayar }\end{array}$ \\
\hline
\end{tabular}




\subsection{Perencanaan Perubahan}

a. Pihak Perguruan Tinggi sebaiknya mengubah cara pembayaran perkuliahan per bulan saja untuk menghindari kelalaian mahasiswa dalam membayar dan untuk meringankan beban pembayaran bagi mahasiswa kurang mampu

b. Kerja sama Perguruan Tinggi dengan pihak luar dalam hal beasiswa bagi mahasiswa yang kurang mampu

c. Adanya keterlibatan orang tua mahasiswa

d. Pihak Perguruan Tinggi sebaiknya menginfokan semua hal yang berkaitan dengan pembayaran perkulian tanpa terkecuali.

\section{Kesimpulan}

Dengan menggunakan pendekatan Soft System Methodology telah berhasil membangun sebuah pemodelan Ekstraksi Knowledge pada proses pembayaran perkuliahan dengan langkahlangkah yang telah diperbaiki sesuai dengan studi kasus.

Pemodelan ekstraksi knowledge ini menghasilkan proses-proses untuk menangkap pengetahuan, menghasilkan dokumen-dokumen pengetahuan yang dapat dimanfaatkan perguruan tinggi dalam menentukan keputusan terbaik terhadap pembayaran perkuliahan yang dapat diketahui oleh mahasiswa, orang tua mahasiswa, dan pihak administrasi dalam mewujudkan pembayaran perkuliahan secara tertib sehingga kegiatan operasional PT dapat berjalan dengan lancar.

\section{Referensi}

[1] Maani, Kambiz E and Robert Y Cavana. 2000. System Thinking and Modelling Understanding Change and Complexity. Pearson Education, New Zealand.

[2] Nugroho, Heru. 2012. Pendekatan Soft System Methodology Untuk Membangun Sebuah Sistem Informasi Proyek Akhir. Konferensi Nasional Sistem Informasi 2012,At STIKOM BALI.

[3] Baretto, Cesario. Dkk. 2017. Soft System Methodology Implementation in Extraction of Knowledge about School Tuition Payment Problem.

[4] Rumetna, S.M., dkk. 2017. Penerapan Knowledge Capture Untuk Promosi Fakultas Menggunakan Soft System Methodology (SSM) Studi Kasus: Fakultas Teknik, Universitas Victory Sorong). Prosiding Seminar Nasional Geotik 2017. ISSN: 2580-8796.

[5] Costa, C.S. dkk. 2017. The Application of Soft System Methodology (SSM) in Extraction of Knowledge in the Field of Research [Case Study: Faculty of Information Communication and Technologies (ITC) in Institute of Business University Dili Timor Leste]. The International Journal of Science \& Technoledge. Vol.5, Issue 9. ISSN 2321-919X.

[6] Wibowo, H\&Setyani, E., 2017. Rancang Bangun Student Payment Dalam Mewujudkan Customer Relationship Managemnt (CRM) Di Perguruan Tinggi. Jurnal Informatika. Vol. 17, No.1, Juni 2017

[7] Davenport, Thomas H \& Prusak, L. 1998. Working Knowledge : How Organizations Manage What They Know. Boston : Harvard Business School Press.

[8] Probst.T\&Brubaker.T.L,. 2001.The effects of job insecurity on employee safety outcomes: Crosssectional and longitudinal explorations. Journal of Occupational and Health Psychology. Vol. 6. No.12, 139-159.

[9]Ikrahmawati. 2016. Pengaruh Knowledge Management Terhadap Kinerja Karyawan (Studi pada PT. Kumala Motor Sejahtera Abadi Kendari).

[10]https://beritati.blogspot.com/2013/02/teknologi-informasi-dalam knowledge.html

[11] Darudiato, S., dan Setiawan, K., 2013. Knowledge Management: Konsep dan Metodologi. ULTIMA InfoSys, Vol. IV, No.1. ISSN 2085-4579.

[12] Rahayu, P., dkk. 2015. A Conceptual Model for Home Budget based on Soft System Methodology and MVC pattern. Open Access Jouenal of Information System (OAJIS).

[13] Kartini. dkk. 2017. Perangkat Lunak Distribusi Bantuan Hibah Menggunakan Soft System Methodology (Studi Kasus: Dinas Perikanan Kabupaten Musi Banyuasin). 